\author{
В.М. Іванов*, А.В. Дубовицька*, Н.В. Вовкотруб** \\ *Дніпропетровський начіональний університет імені Олеся Гончара \\ **КП «Південукргеологія»
}

\title{
ОСОБЛИВОСТІ ЗРУДЕНІННЯ ГАННІВСЬКОГО МОЛІБДЕНОВОГО РУДОПРОЯВУ В КРИВОРІЗЬКО-КРЕМЕНЧУЦЬКІЙ ЗОНІ УКРАЇНСЬКОГО ЩИТА
}

\begin{abstract}
Наводяться нові дані про один 3 найбільш перспективних в Украӥні молібденових об'сктів - Ганнівський рудопрояв. Результати досліджень підтвердили складний, багатостадійний характер рудоутворення на рудопрояві, що виражасться наявністю декількох генерацій піриту й магнетиту, а також просторовою роз'єднаністю молібденіту та інших сульфідів.
\end{abstract}

Ключові слова: молібденове зруденіння, Український щит.

Приводятся новые данные по одному из наиболее перспективных в Украине молибденовых объектов - Анновскому рудопроявлению. Результаты исследований подтвердили сложный, многостадийный характер рудообразования на рудопроявлении, который выражается наличием нескольких генераций пирита и магнетита, а также пространственной разобщенностью молибденита и других сульфидов.

Ключевые слова: молибденовое оруденение, Украинский щит.

The new data about Hannivsky occurrence, ones of molybdenum prospects in Ukraine, are given. The results of researched confirmed a complex, multistage character of ore formation in occurrence, which by availability of some pyrite and magnetite generations, and in the spatial dissociation of molybdenite from others sulfides is expressed.

Key words: molybdenum mineralization, Ukrainian Shield.

Україна, на жаль, поки що не має власної молібденвидобувної галузі. I це при тому, що її надра досить багаті молібденом - стратегічно важливим металом взагалі i, особливо, для країни з міцним гірничо-металургійним комплексом. Між тим, у межах Українського щита (УЩ) виявлено декілька рудопроявів, які можуть бути основою мінерально-сировинної бази цього металу - Вербинський на північному заході УЩ, Східно-Сергіївський у південній частині Сурської зеленокам'яної структури Середньопридніпровського геоблоку та Ганнівський у межах КриворізькоКременчуцької шовної зони. У минулому році в центральній частині останнього (на так званій ділянці «Червона») було проведене пошуковооціночне буріння, результати якого підтвердили високі рудні перспективи об'єкту.

Ганнівський рудопрояв молібдену, відкритий в 60-ті роки минулого століття і раніше описаний у звітах К.Ф.Різдвянського (1975), Л.В.Гальчанського (2004) та інших, а також у публікаціях [1;2], згідно з існуючим районуванням Українського щита (УЩ), розташований у крайній західній частині Середньопридніпровського мегаблоку i в геологічному плані одночасно $\epsilon$ складовою Жовтоводської та північної частини Криворізької структур - так званої Східно-Ганнівської смуги. Зі сходу названі структури залягають на 
нижньопротерозойських гранітах кіровоградського комплексу та гранітах демуринського комплексу верхнього архею, а $з$ заходу обмежені КриворізькоКременчуцькою шовною зоною субмеридіонального простягання, що складена трьома зближеними субпаралельними розломами - Західним, Тарапаківським та Східним. У межах Ганнівського рудопрояву простежено останній розлом, який проходить через всю ділянку, має круте західне падіння під кутами $75^{\circ}-85^{\circ}$ i майже скрізь $є$ границею між породами новокриворізької світи та кіровоградськими гранітами.

Рудовміщуючими на рудопрояві є породи новокриворізької світи ( $\left.\mathrm{PR}_{1} \mathrm{nk}\right)$, що займає нижню частину утворень криворізької серії нижньопротерозоїського віку і вище по розрізу змінюється, відповідно, породами скелюватської ( $\mathrm{PR}_{1} \mathrm{sk}$ ), саксаганської ( $\left.\mathrm{PR}_{1} \mathrm{sx}\right)$ і гданцівської ( $\left.\mathrm{PR}_{1} \mathrm{gd}\right)$ світ.

Комплекс порід новокриворізької світи, яка за своїм первинним генезисом $\epsilon$ вулканогенно-осадовою, представлений амфіболітами роговообманкового, актинолітового, хлорит-амфіболового, актиноліт- i тремоліт-біотитового складу (рис. 1), габро-амфіболітами, сланцями та кварцитами. У складі скелюватської світи присутні кварцити, кварцитопісковики, аркозові пісковики з прошарками сланців. Саксаганська світа складена двома сланцевими та двома залізистими горизонтами. Утворення гданиівської світи присутні у крайній західній частині рудопрояву i представлені сланцями, гнейсами, кварцитами та метапісковиками. Гранітоїди кіровоградського комплексу $\left(\mathrm{PR}_{1} \mathrm{~kg}\right)$, серед яких переважають дрібно- та середньозернисті, інколи порфіробластові смугасті плагіомікроклінові граніти та мігматити, в межах рудопрояву підстилають новокриворізьку світу амфіболітів, формуючи куполоподібні масиви, міжпластові тіла та тіла, що приурочені до лінійних зон тектонічних порушень.

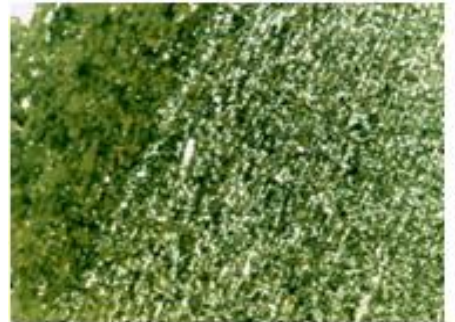

a)

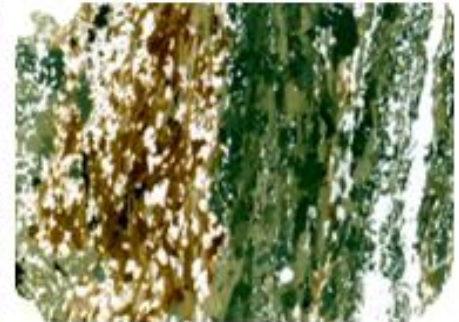

6)

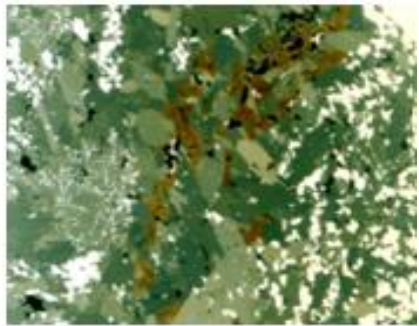

B)

Рис. 1. Різновиді амфіболітів; прозорі шліфи, ніколі паралельні:

а) амфіболіт шаруватий з різною зернистістю окремих прошарків; св. 24744, гл. 237,0 м (довжина по горизонталі 2,2 мм); б-в) хлорит-амфіболові амфіболіти: б) св. 24743, гл. 450,0 м (довжина по горизонталі 2,0 мм); в) св. 24743, гл. 440,1 м (довжина по горизонталі 2,0 мм)

Серед гідротермально-метасоматичних змінень проявлені альбітизація, калішпатизація, скарнування, грейзенізація, окварцювання тощо.

Альбітизація у вигляді прошарків і жил альбітитів, інколи - 3 проявами більш ранньої калішпатизації, в більшій ступені спостерігається у південній частині рудопрояву. 
В амфіболітах виділяються дві зони скарнування (скарноподібних порід або скарноїдів) - високотемпературна, що представлена кордієритантофілітовою асоціацією 3 підпорядкованим розвитком шеєліту, та низькотемпературна 3 розвитком діопсиду, актиноліту, тремоліту, карбонатів, воластоніту, гранату, скаполіту i, суттєво, шеєліту. Скарноподібні породи в більшості локалізуються серед розсланцьованих амфіболітів верхньої частини амфіболітової товщі, поблизу від контакту 3 перекриваючими їі лейкократовими плагіогнейсами, і складають пласто - та лінзоподібні тіла потужністю від десятків сантиметрів до 5-12 м.

Про проявлення процесу, схожого $з$ грейзенізацією, певною мірою свідчить наявність на рудопрояві зон інтенсивного окварцювання та мусковітизації, в яких нерідко містяться кристали турмаліну, виділення флюориту, топазу, рутилу, потужністю від 25 - 30 м до 200 м. У межах цих зон фіксується від 2 до 7 більш інтенсивно грейзенізованих (кварц-серицитмусковітових 3 альбітом, турмаліном, рутилом, іноді флогопітом, флюоритом, топазом) ділянок - «грейзенізитів», потужність яких змінюється від перших метрів до 50 м.

Продукти метасоматичного окварцювання - вторинні кварцити представлені практично мономінеральними кварцовими породами та їх слюдистими різновидами з прошарками мусковітових (серицитових) сланців 3 силіманітом, кордієритом, рутилом, турмаліном, інколи гранатом. Процес прожилкового окварцювання, виражений розповсюдженням переважно субзгідних з загальним розланцюванням вміщуючих порід кварцових 3 підпорядкованими кількостями інших мінералів прожилків (рис.2), $\epsilon$ найбільш яскраво проявленим. Уздовж контактів цих прожилків нерідко спостерігається оторочка, складена більш великими, ніж у вміщуючій породі, виділення амфіболу (рис. 2 а-в).

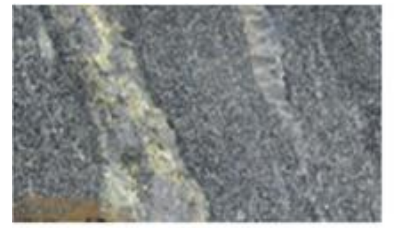

a)

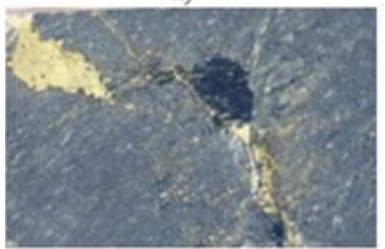

6)

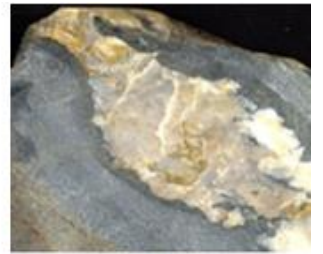

B)

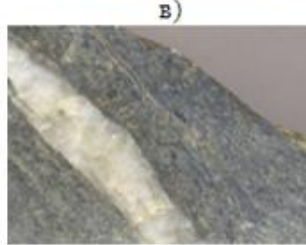

г)

Рис. 2. Прояви дорудного прожилкування та пов'язаної 3 ним амфіболізації; полірований керн: а) розвиток амфіболу на контактах будин і прожилків польовошпат-кварцового складу; св. 24917, гл. 64,2 м; б) розвиток амфіболу на контактах будинованого польовошпат-кварцового прожилку; св.

24917 , гл. 66,3 м; в) крупнозернисті (до 5 - 10 мм у поперечнику) виділення амфіболу в січних сульфідмістячих прожилках; св. 24746, гл. 106,9 м; г) будинований субзгідний прожилок у слюдистокварцовому сланці 
Молібденове зруденіння, за даними буріння свердловин розповсюджене до глибини 500 м, представлене молібденітом, що розпилений у ділянках, збагачених біотитом, а також тяжіє до «сухих» тріщин, ниткоподібних прошарків і малопотужних кварцових, польовошпаткварцових і епідот-кварцових прожилків, переважно субзгідних із загальним заляганням порід амфіболітової товщі та напрямком сланцюватості в них. Домінуюча частина молібденіту знаходиться у породах безпосереднього екзоконтакту гранітоїдів кіровоградського комплексу при незначній його частці, локалізованої саме в гранітоїдах. У прожилках досить часто він відкладений уздовж зальбандів, створюючи або ланцюжки лусочок 3 переважним розміром до 0,5 мм (дуже рідко - до 2 мм), або нібито оторочку, складену пилувато-тонколускатим агрегатом; спостерігаються також гніздоподібні вкраплення лусочок. В аншліфах у більшості встановлені таблитчасті, лускаті, зплощені самостійні виділення молібденіту або їх зростання, в цілому видовжені згідно розсланцюванню та зальбандам прожилків і розташуванню сприятливих для локалізації прошарків; значно рідше зустрічаються окремі дрібні різноорієнтовані лусочки та їх променеві зростання За виключенням піриту, звичайно молібденіт просторово відокремлений від інших рудних мінералів (рис. 3). Молібденіт містить $59,19 \%$ - 60,45 \% молібдену, 39,55 \% - 40,81\% сірки та домішки свинцю $(0,3 \%)$, титану $(0,01 \%)$, вісмуту $(0,01 \%)$, нікелю $(0,01 \%)$, кобальту $(0,003$ $\%)$, міді $(0,0005 \%)$, а також ренію $(0,02 \%)$.

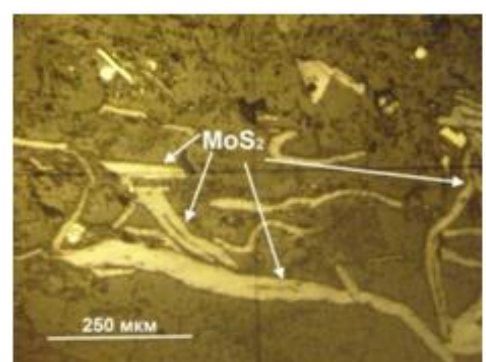

a)

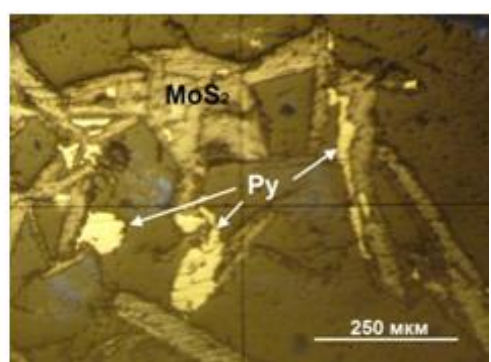

6)

Рис. 3. Особливості розподілу молібденіту $\left(\mathrm{MoS}_{2}\right)$ у вміщуючій породі (Ру - пірит); аншліфи

3 числа інших сульфідів на рудопрояві виявлені наступні: пірит, халькопірит, піротин, арсенопірит, галеніт, вісмутин та сфалерит.

Пірит у складі чотирьох умовно виділених за генетичним походженням типів (сингенетичного, метаморфогенного, гідротермального та метасоматичного) $є$ домінуючим сульфідом. У свою чергу, гідротермальний пірит у зруденілих ділянках $\epsilon$ найбільш поширеним i представлений, як мінімум, двома генераціями.

Пірит, віднесений до першої генерації, різко переважає і частіше представлений виділеннями неправильної, неправильно-подовженої, подовженої, близізометричної та ізометричної форми, розміром (у довжину та поперечнику) до декількох міліметрів та їх зростками. Часто зерна піриту розподілені в субпаралельних тріщинах сланцюватості-шаруватості, таким 
чином підкреслюючи напрямок останньої. Саме від конфігурації тріщин та порожнин часто залежить i форма виділень мінералу. Значно рідше зустрічаються зерна, що характеризуються достатньо гарно проявленим ідіоморфізмом, тобто мають прямокутні, квадратні, ромбовидні, полігональні та інші поперечні перетини; розмір цих зерен, як правило, не перевищує 0,6 - 0,7 мм. Іноді присутні мономінеральні гніздо- та лінзовидні (довжиною до декількох сантиметрів при потужності до 5 мм) відокремлення. Пірит цієї генерації створений явно раніше молібденіту, оскільки в аншліфах неодноразово спостерігались включення молібденіту в зернах піриту, проникнення лусків молібденіту в пірит у периферійних частинах його зерен, випадки «одягання» ними останніх та інші (рис.4,5 ).
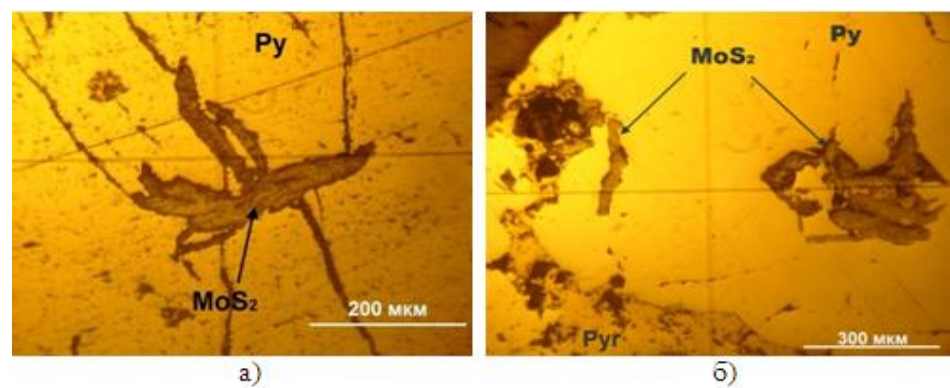

Рис.4. Включення молібденіту $\left(\mathrm{MoS}_{2}\right)$ у піриті першої генерації (Рy), Рyr - піротин; аншліфи

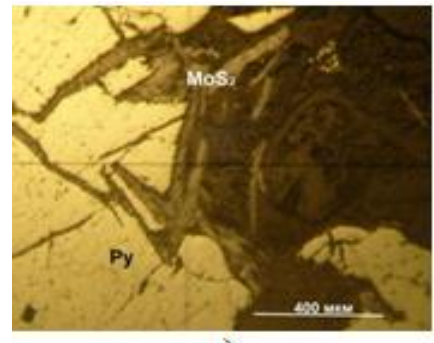

a)

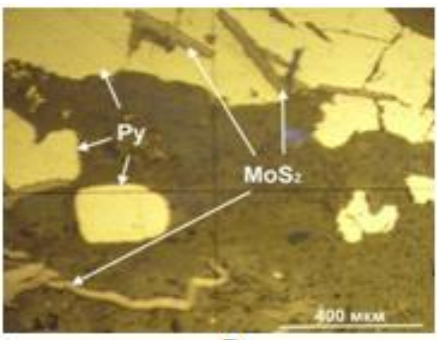

6)

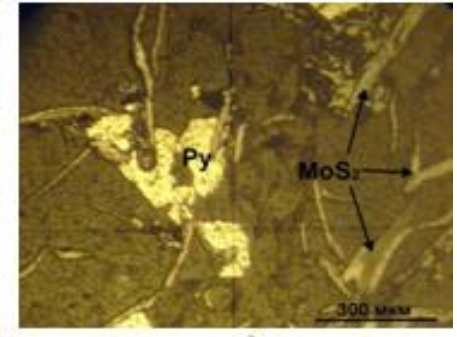

B)

Рис. 5. Взаємовідношення між молібденітом $\left(\mathrm{MoS}_{2}\right)$ та піритом першої генерації (Ру); аншліфи

У піриті, який, за даними визначення на мікроаналізаторі JXA-5 в ІГМР НАН України, має склад, близький до стехіометричного ( 46,72 \% заліза та 52,88 \% сірки при наявності 0,40\% вісмуту та 0,02\% міді), за більш ранніми даними, містяться домішки титану (до 0,3 \%), міді (0,15\%), кобальту $(0,07 \%)$, марганцю $(0,07 \%)$, нікелю $(0,005 \%)$, цинку $(0,005 \%)$, хрому $(0,0015 \%)$, срібла $(0,0003 \%)$, германію $(0,0002 \%)$.

Другий різновид (генерація) піриту, який за часом створення $є$ більш пізнім, має підпорядковане значення i, головним чином, у вигляді тонко- i схованозернистого агрегату нерідко наростає на зерна піриту першої генерації (рис. 6 a), але частіше заповнює пізні тріщини в породі. У свою чергу, ці тріщинки (та, відповідно, просічки піриту) іноді з'єднують між ж 
собою окремі зерна піриту першої генерації (рис. 6 б). Іноді у тріщинах та порожнинах присутні самостійні зерна пізнього піриту, поперечний розмір яких звичайно не перевищує 0,2 - 0,3 мм. Взаємовідношення піриту другої генерації з молібденітом неоднозначні, але більш похоже, що молібденіт січе його.

Халькопірит є другим за промисловим значенням сульфідним мінералом руд. За отриманими даними, присутні дві його генерації, створені метаморфогенним (перша генерація) і гідротермальним (друга) шляхами. Перша 3 них утворює як мономінеральні (більш поширені) виділення неозначеної форми 3 переважним розміром менше 1 мм, так і такі, що знаходяться в зростанні з піритом та магнетитом; іноді спостерігаються лінзовидні зростки зерен халькопіриту. Друга генерація халькопіриту має гідротермальний генезис і пов'язана 3 карбонат-кварцовими прожилками та жилами, в яких він створює виділення неправильної та видовженої (часто по їх простяганню) форми. У тих випадках, коли халькопірит знаходиться в асоціації з піритом, зерна якого володіють значно краще вираженим

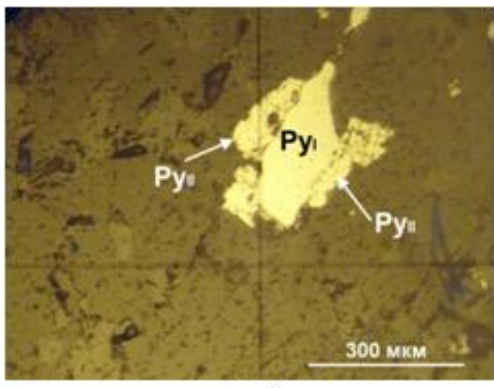

a)

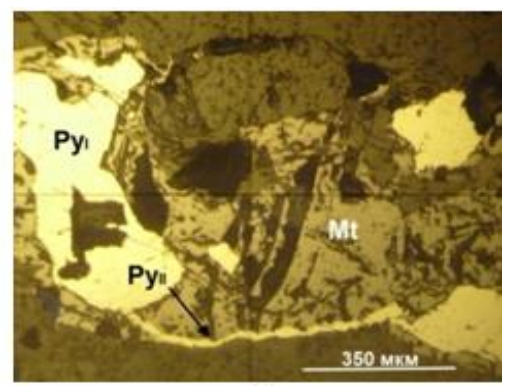

6)

Рис. 6. Взаємовідношення між піритами першої (Ру⿰) та другої (Ру⿰氵) генерацій і магнетитом другої генерації (Mt); аншліфи

ідіоморфізмом, він звичайно наростає на грані останнього, виповнює тріщинки в ньому, а також створює дрібні включення.

Піротин, який за поширеністю серед сульфідів займає друге місце після піриту, переважно приурочений до тріщинуватих ділянок порід, де утворює самостійні виділення неправильної і неправильно-подовженої форми до 2,2 мм довжиною, рідше - таблитчасті, призматичні та близізометричні зерна, поперечний розмір яких звичайно не перевищує $0,5-$ 0,6 мм, а також прожилки довжиною до 1,3 мм. Рідше присутні зростки його зерен неправильної форми до перших міліметрів у поперечнику. Відносно часто він знаходиться в асоціації 3 піритом, наростаючи у вигляді переривистих малопотужних кайм загальною довжиною до 0,7 мм при їх потужності 0,1 - 0,2 мм і самостійних виділень довжиною до 0,5 мм на його зерна, розвиваючись по тріщинкам у ньому. Спостерігаються включення піротину неправильної, подовженої, округлої, краплевидної та іншої форми розміром звичайно не більше 200 мкм у поперечнику та 250 мкм у довжину 
в піриті. Присутні зростки піротин-піритового, піротин-халькопіритового та піротин-пірит-халькопіритового складу. Піротин містить домішки нікелю ( до $0,7 \%)$, марганцю $(0,05 \%)$, міді $(0,03 \%)$, кобальту $(0,01 \%)$, цинку $(0,005$ $\%)$, титану $(0,001 \%)$, свинцю $(0,0002 \%)$.

Apceнопірит у вигляді поодиноких видовжених, довгопризматичних та голчатих кристалів довжиною до 300 мкм, значно рідше - їх агрегатів спостерігається серед кварц-біотит-хлоритових сланців та амфіболітів, особливо в ділянках брекчійування, що зцементовані кварц-карбонатпіритовою речовиною, де іноді він просторово асоційований 3 піритом та халькопіритом. Ідіоморфізм цих кристалів за відношенням до піротину, наприклад, проявлений значно краще.

Галеніт зустрінутий у роговообманкових амфіболітах і представлений одиничними зернами розміром від 0,03 до 1,0 мм (переважно - до 0,25 мм), які нерідко мають кубічну форму, меншою мірою скупченнями зерен, що знаходяться в асоціації з іншими сульфідами, в тому числі - у вигляді суцільної маси в тісному зростанні з вісмутином. До домішок у галеніті відносяться цинк (до $0,05 \%$ ), срібло $(0,01 \%)$, мідь $(0,001 \%)$.

Сфалерит у незначних кількостях зустрінутий в катаклазованих i сульфідизованих (пірит-, піротин-, халькопірит-, галеніт- та молібденітмістячих) роговообманкових амфіболітах та залізистих кварцитах. Виділення сфалериту звичайно мають неправильну форму i поперечний розмір від 0,04 мм до 0,14 мм при переважному розмірі до 0,07 MM.

Вiсмутин виявлений в мінералогічних пробах у вигляді уламків кристалів неправильної форми, суцільних земельних агрегатів, що складають уламки від 0,14 - 0,2 до 0,5 мм у поперечнику. Відмічено наявність переривистої кайми вісмутину навкруги зерен піриту.

До інших рудних мінералів, присутніх у зруденілих зонах рудопрояву, відносяться магнетит (найбільш розповсюджений), шеєліт, вольфраміт, самородні золото та срібло і телурид вісмуту.

Магнетит на рудопрояві представлений двома генераціями, перша 3 котрих за часом створення $\epsilon$ дорудною, а друга - продуктом перерозподілу речовини, що мав місто у процесі внутрішньорудних метасоматичногідротермальних перетворень.

Магнетит першої генерації переважає і знаходиться в кількостях до 25-30\% і більше в незмінених вміщуючих породах. Він представлений вкрапленністю зерен близізометричної, ізометричної (до 1,1 мм у поперечнику) та подовженої форми (довжиною до 1,5 мм), які нерідко створюють ланцюжки, приурочені до тріщин сланцюватості-шаруватості у породі і орієнтовані згідно з останньою.

Магнетит другої генерації, головним чином, знаходиться у виді мономінерального, а також асоційованого $з$ підпорядкованими кількостями сульфідів тонко- і схованокристалічного агрегату, що утворює гнізда рідко більше 1 мм у поперечнику, линзочки та прожилки довжиною до 3 мм. Крім 
того, цей агрегат створює кайми на ранньому піриті (рис.7 а), такого ж типу кайми на піриті, периферійні частини якого раніше вже були покрити виділеннями піротину або халькопіриту, а іноді - обох мінералів (рис.7 б), та магнетиті першої генерацій (рис. 7 в).

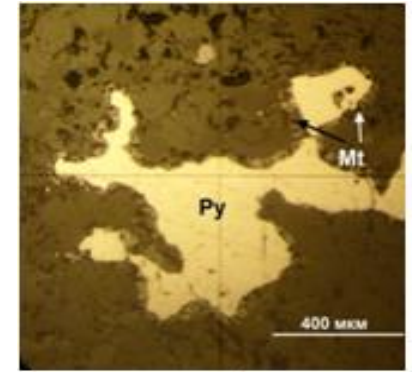

a)

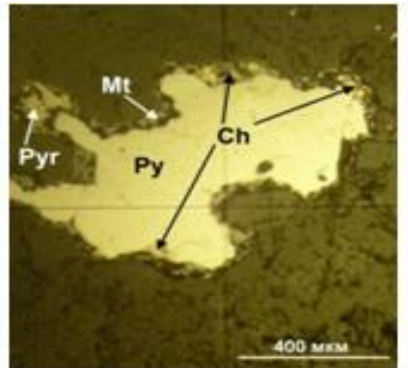

6)

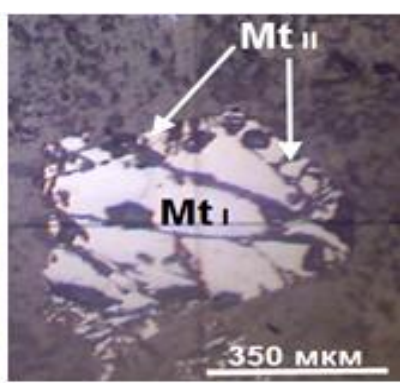

B)

Рис.7. Взаємовідношення між магнетитом другої генерації (Mt тa Mtı), піритом першӧггенерації (Ру), халькопіритом (Ch), піротином (Pуr) та магнетитом першої генерації (Mt $\mathrm{Mt}_{\mathrm{I}}$; аншліфи

Шеєліт, наявністю якого, головним чином, обумовлені підвищені кількості вольфраму (до $0,07 \%$ у пробах) у рудних зонах, утворює ізометричні, овальні і неправильні зерна розміром від 0,003 до 0,8 мм, більшість яких, розташованих субпаралельними ланцюжками, виявлено в кварцовій жилі, що пересічена свердловиною 24737 на глибині 358,3 м. На глибині 359,3 м свердловини 24736, де спостерігається контакт амфіболітів iз залізистими кварцито-сланцями, у зонці окварцювання і сульфідизації зустрічно 2 зерна шеєліту розміром біля 200 мкм та 150 мкм у поперечнику, які знаходяться в просторовій асоціації з неправильної форми виділеннями рудного мінералу.

Другий вольфрамовий мінерал - вольфраміт - $є$ ще більш рідкісним і виявлений в кварцово-двослюдяному сланці з турмаліном та апатитом у свердловинах №№ 24180 та 24188.

Самородне золото пробністю 872 - 902 і незначними домішками міді, ртуті та телуру у вигляді дрібних і тонких виділень, лише окремі з яких досягають 0,2 - 0,3 мм у поперечнику, більшою частиною спостерігається в сікучих шарування порід жилах та прожилках, складених кварцом, карбонатами та сульфідами.

В окремих зразках по свердловині 24748 в слюдисто-кварцових сланцях знайдено декілька дендритовидних виділень самородного срібла довжиною до 8 - 10 мм.

У складі руд виявлено мінерали - носії вісмуту: в зразках та пробах свердловин №№ 24737 та 24748 - самородний вісмут, який, крім саме вісмуту, містить до $0,06 \%$ срібла та 0,04 \% міді; свердловини 24737 мінерал, що за складом не відповідає ні одному з відомих телуридів вісмуту (71,61 \% вісмуту, 22,60 \% телуру, 4,18 \% сірки і домішки селену - 1,6\%, міді - 0,03\% та срібла - 0,01 \%). За вмістом вісмуту останній ближче всього до верліту $\left(\mathrm{Bi}_{2+\mathrm{x}} \mathrm{Te}_{3-\mathrm{x}}\right)$, за вмістом телуру - до чикловіту $\left(\mathrm{Bi}_{2} \mathrm{TeS}_{2}\right)$, за вмістом сірки - до тетрадиміту $\left(\mathrm{Bi}_{2} \mathrm{Te}_{2} \mathrm{~S}\right)$ та жозеїту $\mathrm{A}\left(\mathrm{Bi}_{4+\mathrm{x}} \mathrm{Te}_{1-\mathrm{x}} \mathrm{S}_{2}\right)$. 
Таким чином, проведені останнім часом дослідження особливостей зруденіння Ганнівського рудопрояву підтвердили раніше виказане передбачення про складний, багатостадійний характер формування його комплексних вольфрам-мідь-молібденових (із сріблом, золотом, вісмутом) руд. Це підтверджується, наприклад, наявністю в зруденілих ділянках, як мінімум, двох генерацій не тільки піриту, але і магнетиту. Додатковою ознакою цього може служити також дуже рідкісне спільне знаходження (тобто - не одночасне створення) головного корисного мінералу руд, молібденіту, з сульфідами та іншими рудними мінералами.

\section{Бібліографічні посилання}

1. Бабков Ю.Б. Некоторые особенности размещения медно-молибденовых рудопроявлений в восточной части Криворожско-Кременчугской зоны /Ю.Б. Бабков, А.С. Киселев, В.В. Решетняк, Ю.З. Борзенко //Геол. журн.-1972.№4.-C. 112-114.

2. Великанов Ю.Ф. Условия формирования молибденовой минерализации Восточно-Анновской полосы /Ю.Ф. Великанов, Н.П. Семененко //Геол. журн. 1992.-№3.-C. 89-92.

Надійшла до редколегї 18.04.11. 